Interdisciplinary Contexts of Special Pedagogy
No. 25/2019

\title{
The educational context of the Sejm protest by people with disabilities and their families
}

\begin{abstract}
Magdalena Bełza-Gajdzica, Zenon Gajdzica, The educational context of the Sejm protest by people with disabilities and their families. Interdisciplinary Contexts of Special Pedagogy, no. 25, Poznań 2019. Pp. 83-103. Adam Mickiewicz University Press. ISSN 2300-391X. DOI: https:// doi.org/10.14746/ikps.2019.25.04

This paper presents an analysis of the social reception of a protest by people with disabilities and their families (and guardians), with a special focus on its educational dimension. The protest took place in the main corridor of the Sejm complex in Warsaw in April and May 2017. The first part of the paper comprises the essential characteristics of social protests. The second provides a brief overview of media information about the discussed protest. The recapitulation of this part specifies the conditions that give the protest an educational dimension. From there, the analysis is narrowed to the reception of knowledge pertaining to the situation of the needs of people with disabilities and their families and the change in attitudes to this social group. The third part comprises a presentation of the research results on this issue. The research was conducted with the use of diagnostic polling - the questionnaire technique, applied to a group of 200 people. The research results show that the protest was a kind of information campaign and that it contributed to some changes in respondents' knowledge concerning people with disabilities and their families and the transformation of attitudes to their needs.
\end{abstract}

KEY WORDS: protest, resistance, disability, political debates, media messages 


\section{Introduction}

The words "protest" and "education" paired in the title of this paper connote strong associations with the resistance of teachers (also academic teachers) against changes that serve rash, usually ill-considered and politically driven, reorganisation of education systems. Rightly so, they also bring to mind teachers' strikes in defence of the dignity of the profession, for improvement in working conditions, or for higher remuneration. The issues addressed in this paper go beyond those connotations. The core of the deduction is constituted by an attempt to consider the protest as a process inscribed in the widely understood field of social education. In other words, we focus on viewing the confrontation and rebellion as less a factor of direct transformation of the social order and more as a source of experience and spreading of knowledge on the subjects and objects of the protests.

What contributed to this formulation of the topic is the protest by people with disabilities and their families that took place in the main corridor of the Sejm (Poland's house of parliament) in April and May 2018. This protest became not only an event of social interest but also (or maybe even foremost) a political one and led to wide media coverage. Despite various political connotations, undoubtedly diluting the essence of the issue, the problems of persons with disabilities and their families made their way to the centre of multiple media reports. Thus, one can expect they were noticed and spread within the social sphere. They probably became an object of reflection and discussion in many Polish families, in social groups and milieus that haven't been previously confronted with the problematics. Naturally, the education dimension of the protest may also have extended to the essence and consequences of the experience shared by the protest's participants and by those to whom the protest was addressed. This aspect will be left outside of the focus of our study, however.

The aim of the study is a general characterisation of this protest, with particular attention paid to defining the conditions required 
for the protest to have the effect of spreading knowledge about its purpose and the change of attitude towards the subject and object of the protest. As an empirical example of the undertaken problem, we present you with the result of the research-respondents' declarations on the indicated change.

\section{The core of the protest}

Social protests may take various forms and analysis of them may be entangled in a differentiated approach and expressed in numerous categories. Such protests are identified with a defined form of collective actions in which a protesting social group expressively presents its standpoint while referring to another subject's sense of responsibility ${ }^{1}$. They fall into a wide formula of social restlessness that doesn't come up suddenly as a complete creation. On the contrary, these kinds of protests usually undergo a slow growth process until they develop into a defined form ${ }^{2}$. As the basis of the protests, like in the distant times of the monarchy, is the ineffectiveness of the requests, the emptiness of promises made by rulers, and limited access to values. The accumulated anger of the protesters is always directed at those who represent the system ${ }^{3}$, or in practice, it is addressed to the group deciding on the distribution of goods and allocation of favours. The protest may be the result of decisionmakers breaking laws, ignoring the rules of democracy, or, above all, unfairness and carrying out the particular will of interests associated with members of the group in power.

${ }^{1}$ N. Luhmann, Risk: a sociological theory, Walter de Gruyter New York 1995. Quoted after: P. Matczak, Protest lokalny w Polsce, „Ruch Prawniczy, Ekonomiczny i Socjologiczny" 2000, no. 3, p. 151 (pp. 151-160).

${ }^{2}$ H. Blumer, Niepokój społeczny i protest zbiorowy, [in:] Obywatelska socjologia szkoty chicagowskiej, ed. E. Hałas, RW, KUL, Lublin 1994, p. 97 (pp. 97-118). Transl. into Polish by E. Hałas.

${ }^{3} \mathrm{M}$. Tendera, Protest jako mechanizm równoważenia nierówności społecznych, „Kultura i Społeczeństwo" 2013, no. 2, p. 111 (pp. 110-132). 
Social protests are placed in the larger concept of resistance, which is related to relations of subordination, dominance, and conflicts. The essence of resistance is to oppose the external influence and impact ${ }^{4}$ and creates the basis for the event of a protest. In the case of people with disabilities and their parents, the grounds for the protest was resistance (disagreement) against the unfair distribution of goods (according to the protesters).

Protest is a form of disagreement with the existing social order (or economic, legal order) and in this sense, it fits into the category of non-conformist disobedience as far as following the norms of that order is concerned. One further form is civil disobedience. It is worth noting, however, that civil disobedience is an illegal act with symbolic meaning, in the sense of being overt, morally justified, devoid of violence, even if it may also happen to be an egoistic attempt to take advantage of the common good. The breaking of the law inherent in this type of disobedience constitutes a kind of message about the imperfections that require political rectification ${ }^{5}$. Nevertheless, breaking the law is not the effect of every protest. On the contrary, some actions use the entitlement given within the democratic system. Hence, not every protest takes the shape of typical civil disobedience in the literal sense. Protests treated as unconventional political actions may adopt diverse forms, from petitioning, to strikes and demonstrations, to even self-immolation ${ }^{6}$.

Every protest, however, is an expression of rebellion. In one of the most popular conceptions, considered within the aspect of so-

4 P. McLaren, Rytualne wymiary oporu - błaznowanie $i$ symboliczna inwersja, "Nieobecne Dyskursy” 1994, no. 1; H.A. Giroux, L. Witkowski, Edukacja i sfera publiczna. Idee pedagogiki radykalnej, Impuls, Kraków 2010; E. Bielska, Koncepcje oporu we wspótczesnych naukach społecznych. Główne problemy, pojęcia, rozstrzygnięcia, UŚ, Katowice 2013.

${ }^{5}$ M. Kaczmarczyk, Niepostuszeństwo obywatelskie a demokracja, "Studia Socjologiczne" 2013, no. 1, p. 25 (pp. 22-40).

${ }^{6}$ G. Ekiert, J. Kubik, Protesty społeczne w nowych demokracjach: Polska, Stowacja, Wegry i Niemcy Wschodnie (1989-1994), „Studia Socjologiczne” 1997, no. 4. 
cialisation, by Robert Merton, protest means an adaptation process in which there is the rejection of values formulated for social goals and of norms, that is, established and accepted methods of achieving those values ${ }^{7}$. Rebellion appears as a result of frustration and dissatisfaction, and usually it comes with a proposal for change, with an alternative suggesting the replacement of elements of the dominant culture by elements of another, dominated/alternative culture ${ }^{8}$. In practice, it is also an attempt to abolish the status quo of the economic, legal, or social order and a proposal for change.

Protests are often analysed in a political context. This is legitimate, as the intention of every protest is to incite a reaction from the political system and introduce more or less deep corrections. What lies at the source of every protest is conflict, in other words, a dispute between two or more interdependent parties. The parties believe that their goals are discordant and resources limited, and they claim that both parties reciprocally interfere with each other in accomplishing their own goals 9 . An important element of protest is demands ${ }^{10}$. They usually stir the greatest controversy and create an axis of conflict while also being the object of negotiations.

It is not possible to present a thorough list of characteristics of a theoretical protest within the limited framework of this paper, and besides, it has been done very accurately in the above-quoted works by authors specialised in the problematics of social confrontation. By evoking a short outline of relative categories that create diversified perspectives of a protest, we intend only to draw your attention to plausible paths of research and analyse its educational value.

${ }^{7}$ R. Merton, Teoria socjologiczna i struktura społeczna, PWN, Warszawa 2002, pp. 221-222. Transl. into Polish by E. Morawska, J. Wertenstein-Żuławski.

8 P. Sztompka, Socjologia. Analiza społeczeństwa, Znak, Kraków 2002, p. 282.

9 W.W. Wilmont, J.L. Hocker, Konflikty między ludźmi, Wydawnictwo Naukowe PWN, Warszawa 2011, p. 32. Przeł. M. Hőffner.

${ }^{10}$ P. Matczak, Protest lokalny w Polsce, "Ruch Prawniczy, Ekonomiczny i Socjologiczny" 2000, no. 3, p. 152 (pp. 151-160). 


\section{Educational conditioning as it pertains to the Sejm protest by people with disabilities and their parents}

A social/political protest as a process and phenomenon remains a particular area of interest for sociology, management science, and more rarely, of psychology or history. Thus, the problem of the educational dimension of a protest (in the sense of social learning) is rather absent from the scientific discourse. Nevertheless, every protest is a lesson, both for the governing side and the governed. It also constitutes an event that spreads given knowledge while promoting specific viewpoints, ideologies, ideas, or concepts. What remains at the centre of our interest is not the lesson that the political elites and protesters themselves 'receive' as a result of experiencing the protest, but foremost the question of knowledge spread by media on the topic and object of the confrontation. One can assume that spreading various perspectives of knowledge about the protesters' expectations may alter the public's view of them and their needs. This explains why an attempt to define the conditions for spreading knowledge presents itself as a nontrivial scientific problem, and its placement in the pedagogical perspective is justified by its practical educational impact. The protest that is the subject of our research also takes place amid the problematics of diagnosis and the creation of social attitudes towards people with disabilities, which makes it relevant from the point of view of special needs pedagogy and other disciplines of disability science.

The protest by people with disabilities and their families took place in the corridor of the Sejm complex in Warsaw. It started on 18 April and finished on 27 May 2018, lasting then for 40 days. Among its participants were people with disabilities (adults and children) accompanied by 18 parents (17 mothers and 1 father $)^{11}$.

11 See: E. Górnikowska-Zwolak, Stowo wprowadzające (o prawach osób z niepetnosprawnościami i o pracownikach nauki z niepetnosprawnościa - edukacyjny wymiar pewne- 
According to the assumptions about protests explicated earlier, they usually aim to achieve specific goals. In this case, it was, above all, to improve the economic situation of families raising people with disabilities. The expectations were composed of two main demands and several additional ones: first, to equalise the person's social pension with that of the minimal pension owing to inability to work, and to introduce an allowance 'for living expenses', also called 'rehabilitation allowance', for disabled persons incapable of self-sufficient existence after reaching 18 years old and amounting to 500 PLN per month ${ }^{12}$. It is worth noting that at the time of the protest, a period of intense economic growth in Poland was continuing, which was transpiring hand in hand with the improvement of the material situation of at least several social groups. This fact resulted in increased possibilities to support select social groups through public support programmes and in raising the remunerations of certain professional groups. In practice, the conditions awakened dormant expectations for support also in groups omitted from this process and created a sense of the unfair distribution of redistributable capital. This problem is illustrated by two rules of justice elaborated by John Rawls ${ }^{13}$. The consequence of his second rule is the assumption that regardless of how much the situation of a person improves, it doesn't matter as long as another person doesn't take advantage of $\mathrm{it}^{14}$. In other words, the rule of distributive justice consists of equally raising participation in goods' distribution, including par-

go zdarzenia), „Problemy Edukacji, Rehabilitacji i Socjalizacji Osób Niepełnosprawnych" 2018, vol. 27, p. 12 (pp. 9-18); K. Klinger, M. Topolewska, Koniec protestu niepetnosprawnych: Niejednoznaczny bilans 40 dni spędzonych w Sejmie, "Gazeta Prawna” 28.05.2018, https://www.gazetaprawna.pl/artykuly/1126506,koniec-protestu-nie pelnosprawnych-w-sejmie.html (May 2018).

12 „Wywalczyliśmy kolejny kamyczek". Protestujący rodzice spisali swoje postulaty https://www.tvn24.pl/wiadomosci-z-kraju,3/sejm-protest-rodzicow-dzieci-niepel nosprawnych-spisali-postulaty,831084.html (February 2019).

${ }^{13} \mathrm{~J}$. Rawls, Teoria sprawiedliwości, Wydawnictwo Naukowe PWN, Warszawa 2013. Transl. into Polish by M. Panafiuk, J. Pasek, A. Romaniuk.

${ }^{14}$ Ibid, p. 128. 
ties that aren't direct consumers of the growth. People with disabilities and their families certainly belong to that group.

Testing the validity of this economic postulate, as usually happens in such cases, raised controversy. In general, however, among the media coverage, the dominant opinion concerned the legitimacy of the formulated expectations and comments expressing comprehension and support for the situation of the adults with disabilities and their families ${ }^{15}$.

As for the conditions of the educational role of the protest, it appears that the clear specification of the demands and their justification (in the context of the general economic situation and negligence on the part of the state in taking care of the needs of people with disabilities) constituted the first, initial requisite ${ }^{16}$. It was the rational justification of that specific rebellion that brought with it a considerable amount of knowledge about the social and economic situation of the protesters.

The second important requirement for spreading knowledge resulted from the form of the protest, and even more, the place of protest. It is worth noting that people with disabilities have limited means of protest: petitions and demonstrations are relatively benign for the ruling party. In these circumstances, taking over space in the main corridor of the Sejm complex was quite an uncomfortable solution for the governing elite and ensured media coverage of the confrontation. Thus, the second condition establishing the educational role of the protest was fulfilled: media broadcasts allowed it to reach a wide spectrum of viewers. The place of protest facilitated numerous direct reports revealing the everyday struggles of the

15 Protest rodziców osób niepetnosprawnych w Sejmie trwa. „Nie wierzymy w polityków", https://www.polskieradio.pl/7/473/Artykul/2101054,Protest-rodzicow-osobniepelnosprawnych-w-Sejmie-trwa-Nie-wierzymy-w-politykow; RON\# za niezależnym życiem, https://www.facebook.com/pg/RodziceON/posts/ (February 2019).

16 Rodzice osób niepetnosprawnych wrócili do Sejmu. Stawiaja twarde warunki, https:/ / www.newsweek.pl/polska/spoleczenstwo/protest-rodzicow-dzieci-niepel nosprawnych-w-sejmie/5rck7es (February 2019). 
families raising people with disabilities. The reports revealed the difficulty of simple hygienic acts, moving, communicating with others $^{17}$, and, which seems to be the most relevant, the emotions of the disabled people and their families at conducting these routine acts. It would be hard to overestimate the educational value of these messages ${ }^{18}$, which were included in reports by all significant Polish media.

The third condition for effective social education deduced from the protest is certainly a matter-of-fact debate about the demands and their entire economic and social context. This requisite, in our opinion, was not met. There was no shortage of statements describing the process as purely political in character ${ }^{19}$. In the debate, arguments distant from the real problems of people with disabilities and their families appeared, such as the purported unethical advantage of parents using their disabled children to accomplish their own political goals, verbal scuffles and sterile arguments about which government did more for disabled people, or, lastly, opinions contesting the need for financial support of this social group ${ }^{20}$. As a result, irrational, extreme opinions flowed and blurred the essence of the protest (such as the financial consequences of the protest in

17 Trwa protest opiekunów osób niepetnosprawnych. Jak wygląda ich życie na sejmowych korytarzach? "Będziemy walczyć. Mamy mnóstwo sity”, https://polskatimes.pl/ trwa-protest-opiekunow-osob-niepelnosprawnych-jak-wyglada-ich-zycie-na-sejmo wych-korytarzach-bedziemy-walczyc-mamy-mnostwo-sily/ar/13128666 (February, 2019).

18 Protest w Sejmie. Kalendarium. Dzień po dniu, http://www.niepelnospraw ni.pl/ledge/x/650943 (February, 2019).

${ }^{19}$ Apolityczny protest w Sejmie? "Zróbcie wszystko, aby nikt z PiS-u nie dostat się do samorząu", https://www.tvp.info/37214676/apolityczny-protest-w-sejmie-zrob cie-wszystko-aby-nikt-z-pisu-nie-dostal-sie-do-samorzadu (February, 2019); Opozycja zapłaci za protest niepetnosprawnych w Sejmie? I to dosłownie, http://www.super stacja.tv/wiadomosc/2018-05-22/opozycja-zaplaci-za-protest-niepelnosprawnychw-sejmie-i-to-doslownie/ (February, 2019).

${ }^{20}$ Radykalna zmiana zdania? Polacy nie chca już protestu w Sejmie, a przynajmniej tak twierdza „Wiadomości” TVP, https://natemat.pl/238671,protest-niepelnospraw nych-w-sejmie-polacy-radykalnie-zmienili-zdanie (February, 2019). 
the context of parliament's work $)^{21}$, thus distorting the authentic needs of the protesters. This dilution most certainly hindered the flow of dependable information about the life, needs, and possibilities of people with disabilities and their families.

As far as the educational balance of the protest is concerned, media statements by representatives of the political elites were also divided. The opinion that the introduction to the public debate of the problematics of disabilities and potential solutions had a positive impact. Politicians themselves 'made quite a lot of progress' as they had to be prepared for frequent questions from journalists concerning the problems of disabled people and possible actions to help them ${ }^{22}$. However, there were voices, especially expressed later on, that it was not a sufficient lesson for the governing party ${ }^{23}$.

An incredibly pertinent evaluation of the educational dimension of the protest in relation to the larger part of society was expressed by Elżbieta Górnikowska-Zwolak:

'Even though the protesters did not see a large part of their demands fulfilled, the effort of resisting in protest did not go to waste; it had powerful educational value. During the protest, all of us, Polish society, representatives of various groups and circles, as well as individuals free in their decisions and responsible for taking action or restraining from it, had the opportunity to see ourselves in it like in a mirror. The picture we saw is multidimensional, ambiguous, but all in all, not quite reassuring ${ }^{24}$.

The mirror metaphor reflects Polish society's flaws 25 : the inclination to depersonalise the weak by the strong, to push the weakest

${ }^{21}$ Kancelaria Sejmu podliczyła koszt protestu osób niepetnosprawnych, https:/ / busines sinsider.com.pl/wiadomosci/koszt-protestu-niepelnosprawnych-w-sejmie/7clbq53 (February, 2019).

${ }^{22} \mathrm{~K}$. Klinger, M. Topolewska, Koniec protestu niepetnosprawnych...

23 "O osobach niepetnosprawnych się nie pamięta". Będzie protest po obietnicach PiS https://www.tvn24.pl/wiadomosci-z-kraju,3/protest-osob-niepelnosprawnych-iich-opiekunow-po-obietnicach-pis,912870.html (May 2019).

${ }^{24}$ E. Górnikowska-Zwolak, Stowo wprowadzajace..., pp. 12-13.

25 Certainly also a base for relationship-building with people with disabilities and construction of the very disability. See: A., Gustavsson, E. Zakrzewska-Man- 
off to the margins, the lack of support for them from academic elites, perfectly exemplified by the author's quote when referring to specific events and media statements ${ }^{26}$. As a consequence, these flaws led to an uncontrite attitude among politicians and the lack of an authentic willingness to compromise.

Ambiguous opinions on the educational dimension of the protest and on the effects on attitudes towards people with disabilities encouraged us to pursue our own exploration and to attempt to formulate an opinion based on the conducted research, as we show below.

\section{Research concept}

The data presented below constitute an excerpt of larger research on the social reception of the protest. The research was conducted by means of a diagnostic survey - questionnaire technique. The survey was composed of seven closed-ended questions regarding various aspects of the perception of the protest and its effects, as well as a few questions aimed at a characterisation by the respondents. Below are presented statements regarding the change in the extent of knowledge about people with disabilities and declarations about the attitudes towards supporting them. The two research questions were:

- What is the link between the protest and the respondents' declarations about the change in their knowledge about people with disabilities?

- What is the link between the protest and respondents' declarations about the change in their support of people with disabilities and their families?

The number of people interviewed was 200, selected according to their availability; the questionnaires were distributed by the

terys, Wprowadzenie: społeczny kontekst upośledzenia, [in:] Upośledzenie w społecznym zwierciadle, eds. A. Gustavsson, E. Zakrzewska-Manterys, Żak, Warszawa 1997.

26 E. Górnikowska-Zwolak, Stowo wprowadzajace..., p. 13. 
authors of the article in various milieus, with the exception of environments directly related to the disabled persons, including also special needs pedagogues and students of pedagogical science. The research was conducted in four districts: Bielsko, Cieszyn, Jastrzębie, and Żywiec. The group isn't entirely representative (because it doesn't reflect layers of the social structure by age, education, or declared political inclinations or interest in domestic politics), its size, however, gives grounds to outline the tendencies regarding the issue $^{27}$. The research was conducted in two waves (on other cohorts - in agreement with the assumption to avoid double questioning of respondents with the same questions) in June, immediately after the protest had ended (100 people), and half a year later in December (100 people). The goal of this strategy was to discover the durability of the presented declarations. We treat the problematics (located in 'social memory'28) with distance, however, as the demographic structure of the examined cohorts was slightly different.

Due to the defined topic of the study, we limit the presentation of the results of our research to the question of a change of knowledge and support for people with disabilities and their families. The restricted frame of our study doesn't allow us to present a larger range of relations (variables differentiating the declarations). Nevertheless, we consider the presented results in the context of one independent variable, that is, the declaration of interest in political discourse. We are convinced that this seemingly prosaic juxtaposition allows us to depict the problem of the reach of media coverage to groups diversified as far as their interest in political and social affairs is concerned.

27 According to the assumption that a large group of people (more than 100) reduces the demographic fluctuations and represents the population more accurately, raising the viability of the application. See: M. Łobocki, Wprowadzenie do metodologii badań pedagogicznych, Impuls, Kraków 1999, p. 172.

28 Understood as a collection of memories of a collective's members about its past, its population and past events, as well as the methods of commemoration and transfer of knowledge that are considered to be obligatory equipment of the community member. See: B. Szacka, Czas przeszły, pamięć, mit, Scholar, Warszawa 2006, p. 41. 


\section{Educational dimension of the Sejm protest by people with disabilities and their parents: results of the research, presentation and comments}

The data analysis indicates that for slightly more than a half of the respondents, the debates taking place around the protest were a reliable source of information entailing a change in their knowledge about people with disabilities and their families (see Figure 1). It is worthwhile to add that the research periods diversified the declarations only to an insignificant extent, which leads us to the conclusion that the protest remained in the immediate social memory, at least in the six-month perspective from the day it concluded.

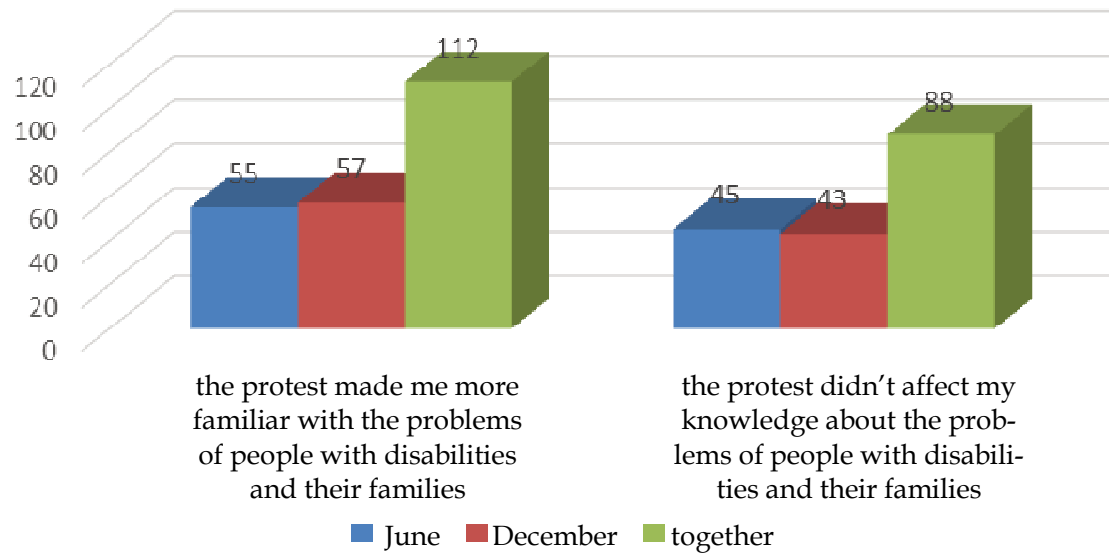

Fig. 1. Declaration of modification of knowledge abour people with disabilities and their families after the protest $(\mathrm{N}=200)$

Naturally, these declarations might be considered as two separate perspectives. The first one shows relevant change, as more than half of the respondents learnt something about the situation, needs, possibilities, and the everyday life of people with disabilities. 
It's hard to think of any information campaign that would entail a change of this range. The other declaration demonstrates that the intensity and quality of the news didn't suffice to extend the knowledge of the strong majority of respondents. Possibly, the often politicised and, more often than not, sterile discourse (dominating at least some of the coverage) did not provide matter-of-fact information and, consequently, it didn't affect - in the case of almost half of the respondents-their level of knowledge. Another question raised is the departure point of the respondents' knowledge about the discussed topic. The group could have comprised a high percentage of respondents who already had at least a basic level of knowledge about the life of people with disabilities. Most of the information transmitted by media could have been for them merely repetition or reaffirmation of facts already known. Doubtless, also some respondents declaring their knowledge level had not increased, are not interested in the social and political discourse, and therefore didn't engage with the reports. The results of this relation are presented in Figure 2.

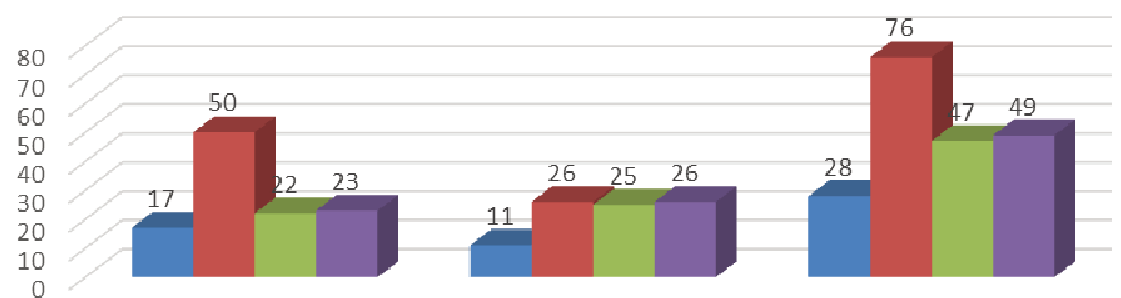

the protest made me more the protest didn't affect my together familiar with the prob- knowledge about the problems of people with disa- lems of people with disabilities and their families bilities and their families

I'm interested and I follow the majority of political debates

I'm interested, but I follow political debates only on occasion

I'm not interested and I occasionally follow political debates

I'm not interested and I never follow political debates

Fig. 2. Interest in politics vs declaration of modification of knowledge about people with disabilities after the protest $(\mathrm{N}=200)$ 
Statistical data analysis $\left(\chi^{2}=6.45 / \mathrm{df}=3 /, \mathrm{p}=0.091\right.$; ni. $\left.{ }^{29}\right)$ indicates that the relation between the analysed declarations is not statistically relevant ${ }^{30}$. The strength of the relation $(C=0.179)$ is located in the range of 'almost irrelevant' ${ }^{31}$. These results may surprise, especially in the groups declaring no interest in politics, and none or little interest in following political debates. A common-sense thesis should assume a decisively lower percentage than in other groups of those declaring a change in their level of knowledge. These groups comprised nearly half of all the respondents, and the differences in the declarations of the two groups, when summed up, fit within the range of a few indications (with the majority of declarations being no change in knowledge). Slightly greater differentiation (in favour of declarations of a change in knowledge) concerns the indications in the group most interested in media-reported political news. An apparent differentiation, however, is characteristic for the group that declares having an interest in the debate and following it occasionally. We may, therefore, make an assumption that moderate involvement and occasional following of media coverage entailed the strongest declaration of the accomplishment of the educational dimension of the protest. In the remaining groups, this aspect followed the average. Possibly, the involved group was affected by tiredness, and the very reception of knowledge was diluted by political saturation. While in the groups weakly interested in political life, the intensity of following media wasn't sufficient to obtain a higher educational effect. This thesis, however, requires confirmation through additional study.

The research is comprised of the cognitive component of attitude. Knowledge about people with disabilities is bound to elimi-

${ }^{29}$ As the level of relevance in our work, we adopted the value of 0.05 , the most common in the social science. See: W.P. Zaczyński, Statystyka w pracy badawczej nauczyciela, Żak, Warszawa 1997, p. 39.

${ }^{30} \mathrm{In}$ this research, we omit the division into research periods.

${ }^{31}$ Based on the convergence indicator of $C$. Pearson describing the degree of relation between variables. See: G.O. Ferguson, Y. Takane, Analiza statystyczna w psychologii i pedagogice, PWN, Warszawa 1997, p. 248. 
nate stereotypes about them, and thus, help one to understand actions to their benefit and as a result to take up actions aimed at an improvement in the social and economic situation of the discussed group of people 32 . Declarations of support for people with disabilities are comprised within the affective component of attitude: endeavour to undertake specific actions for the sake of the subject of the attitude. Identification of the changes within the declarations of support constitutes a continuation of the problematics in question, the educational dimension of the protest.

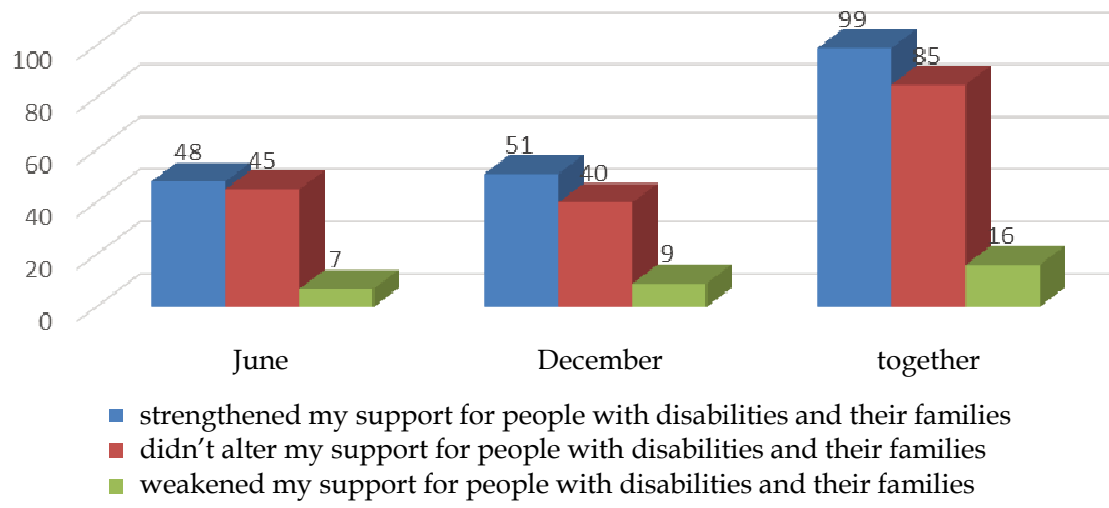

Fig. 3. Declaration of a modification in support of people with disabilities and their families after the protest $(\mathrm{N}=200)$

The results of that research are presented in Figure 3. Analysis of the declarations demonstrates that more than half of the respondents modified their support towards people with disabilities and their families as a result of the protest. In this group, decisively most numerous are respondents who declared a change in a positive direction (strengthening) 33 , only slightly more than 10 people

32 Por. I. Chrzanowska, Pedagogika specjalna. Od tradycji do wspótczesności, Impuls, Kraków 2105, pp. 90-98.

33 The emotional-judgmental component expresses the aspect of the attitude (positive or negative) towards the object of the attitude. That's how we can talk 
chose the opposite direction of change. Nevertheless, both groups show a change in the indicator of the attitude in question, thus proving the educational dimension of the protest. Even though the weakening of support evokes negative connotations, it's beyond doubt that it results from the respondents' reception of the defined information presented in media.

Also, in the case of these results, the data was not differentiated by research period in a substantial way, although polarisation was detected: the number of declarations reporting strengthening and weakening support increased. Still, it would be hard to talk about a relevant change taking place after half a year gap. The results confirm the thesis about the relatively strong influence of the protest, as it remains in the respondents' memory. It is even more relevant as during the first and second research stage, the news about disabled people was quite incidental after the end of the protest, being pushed away from the main current of social, political, and economic problems.

Similarly, we compared these data with declarations about the following political debates. The results are presented in Figure 4. Statistical analysis of the data (like in the analogical comparison regarding the previously defined relation) did not prove any statistically relevant differences. $\left(x^{2}=6.37 / \mathrm{df}=6 /, \mathrm{ni}\right.$.; $\left.C=0.126\right)$.

It's worthwhile to note the subtle differences, the first one being the indicator of the number of declarations of no change in support for people with disabilities in the group of people disinterested in political debates - this is the only group where it's higher from the number of indications of strengthened support. The other one is the relatively strongest percentage of indication of increased support in the contrasting group comprising people most interested in media news of a political character. It demonstrates that the educational role of the protest should not be depreciated, which appears to be obvious, particularly among people interested in the political discourse.

about positive or negative direction. See: M. Marody, Sens teoretyczny a sens empiryczny pojęcia postawy. Analiza metodologiczna zasad doboru wskaźników w badaniach nad postawami, PWN, Warszawa 1976, pp. 17-18. 


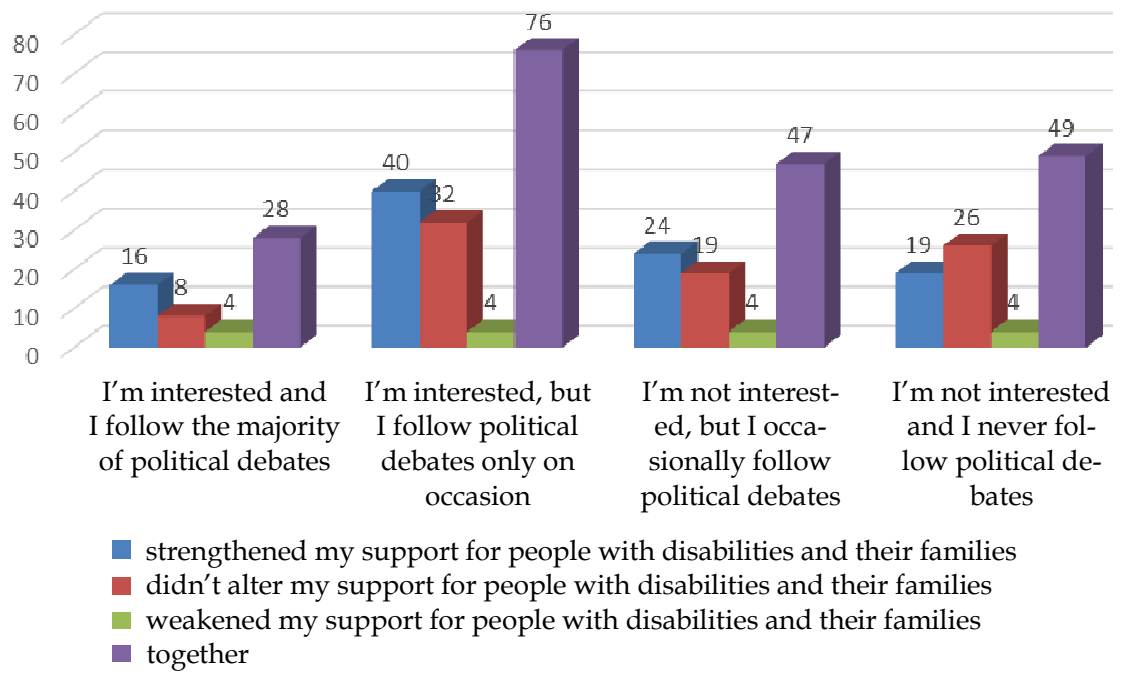

Fig. 4. Interest in political life vs declarations of change in support for people with disabilities and their families after the protest $(\mathrm{N}=200)$

\section{Conclusion}

This short review of the effect of media news regarding the Sejm protest by people with disabilities and their families, presented in this paper, reveals several aspects of the protest action. Without doubt, the most crucial one from the protesters' point of view was the attempt of putting pressure on the authorities and obtaining economic benefits. Also, not only the demands themselves but also the place of protest provoked a lot of controversy, mostly in the political sense. This politicisation blurred the core goal of the demands and weakened the matter-of-fact debate about the authentic situation of people with disabilities. Nevertheless, this fact doesn't change our opinion that the protest's very resonance was conducive to spreading information about the subject while also provoking a debate outside of politics about the directions of change in this area. Media popularisation brought knowledge about the problems 
of people with disabilities and at least partly fostered change in the perception of the need for support of the group in question. In a way, it was a specific information campaign, probably one of the most effective when it comes to the promotion of knowledge about the life and needs of disabled people. To that extent, we note the education value of the protest, which our research has confirmed. We may then state, that the protest (by definition regarded as a conflict, a social event with a negative connotation) bore benefits not only for the protesters but also for building a civic society, which certainly connotates the construction of a social culture of inclusion.

\section{Bibliography}

Apolityczny protest w Sejmie? "Zróbcie wszystko, aby nikt z PiS-u nie dostat się do samorzadu", https://www.tvp.info/37214676/apolityczny-protest-w-sejmie-zrobciewszystko-aby-nikt-z-pisu-nie-dostal-sie-do-samorzadu (February, 2019).

Bielska E., Koncepcje oporu we wspótczesnych naukach społecznych. Główne problemy, pojęcia, rozstrzygnięcia, UŚ, Katowice 2013.

Blumer H., Niepokój spoteczny i protest zbiorowy, [in:] Obywatelska socjologia szkoty chicagowskiej, ed. E. Hałas, RW, KUL, Lublin 1994 (pp. 97-118). Transl. into Polish by E. Hałas.

Chrzanowska I., Pedagogika specjalna. Od tradycji do współczesności, Impuls, Krąków 2105.

Ekiert G., Kubik J., Protesty społeczne w nowych demokracjach: Polska, Stowacja, Wegry $i$ Niemcy Wschodnie (1989-1994), „Studia Socjologiczne” 1997, no. 4.

Ferguson G. O., Takane Y., Analiza statystyczna w psychologii i pedagogice, PWN, Warszawa 1997, p. 248.

Giroux H. A., Witkowski L., Edukacja i sfera publiczna. Idee pedagogiki radykalnej, Impuls, Kraków 2010.

Górnikowska-Zwolak E., Stowo wprowadzające (o prawach osób z niepetnosprawnościami i o pracownikach nauki z niepetnosprawnościa - edukacyjny wymiar pewnego zdarzenia), „Problemy Edukacji, Rehabilitacji i Socjalizacji Osób Niepetnosprawnych” 2018, vol. 27 (pp. 9-18).

Gustavsson A., Zakrzewska-Manterys E., Wprowadzenie: społeczny kontekst upośledzenia, [w:] Upośledzenie w spotecznym zwierciadle, eds. A. Gustavsson, E. Zakrzewska-Manterys, Żak, Warszawa 1997.

Kaczmarczyk M., Niepostuszeństwo obywatelskie a demokracja, „Studia Socjologiczne 2013, no. 1 (pp. 22-40). 
Kancelaria Sejmu podliczyła koszt protestu osób niepetnosprawnych, https://businessin sider.com.pl/wiadomosci/koszt-protestu-niepelnosprawnych-w-sejmie/7clbq53 (February, 2019).

Klinger K., Topolewska M., Koniec protestu niepetnosprawnych: Niejednoznaczny bilans 40 dni spędzonych w Sejmie, "Gazeta Prawna” 28 May 2018, https://www.gazeta prawna.pl/artykuly/1126506,koniec-protestu-niepelnosprawnych-w-sejmie.html (May 2018).

Luhmann N., Risk: a sociological theory, Walter de Gruyter New York 1995.

Łobocki M., Wprowadzenie do metodologii badań pedagogicznych, Impuls, Kraków 1999.

Marody M., Sens teoretyczny a sens empiryczny pojęcia postawy. Analiza metodologiczna zasad doboru wskaźników w badaniach nad postawami, PWN, Warszawa 1976.

Matczak P., Protest lokalny w Polsce, „Ruch Prawniczy, Ekonomiczny i Socjologiczny" 2000, no. 3 (pp. 151-160).

McLaren P., Rytualne wymiary oporu - błaznowanie i symboliczna inwersja, „Nieobecne Dyskursy" 1994, no. 1.

Merton R., Teoria socjologiczna i struktura społeczna, PWN, Warszawa 2002. Transl. into Polish by E. Morawska, J. Wertenstein-Żuławski.

"O osobach niepetnosprawnych się nie pamięta". Będzie protest po obietnicach PiS https://www.tvn24.pl/wiadomosci-z-kraju,3/protest-osob-niepelnosprawnychi-ich-opiekunow-po-obietnicach-pis,912870.html, (May 2019).

Opozycja zaptaci za protest niepetnosprawnych w Sejmie? I to dostownie, http://www.su perstacja.tv/wiadomosc/2018-05-22/opozycja-zaplaci-za-protest-niepelnospraw nych-w-sejmie-i-to-doslownie/ (February 2019).

Protest rodziców osób niepetnosprawnych w Sejmie trwa. "Nie wierzymy w polityków", https://www.polskieradio.pl/7/473/Artykul/2101054,Protest-rodzicow-osobniepelnosprawnych-w-Sejmie-trwa-Nie-wierzymy-w-politykow; RON\# za niezależnym życiem, https://www.facebook.com/pg/RodziceON/posts/ (February 2019).

Protest w Sejmie. Kalendarium. Dzień po dniu, http://www.niepelnosprawni.pl/ledge/ x/650943 (February, 2019).

Radykalna zmiana zdania? Polacy nie chca już protestu w Sejmie, a przynajmniej tak twierdza "Wiadomości" TVP, https://natemat.pl/238671,protest-niepelnospraw nych-w-sejmie-polacy-radykalnie-zmienili-zdanie (February 2019).

Rawls J., Teoria sprawiedliwości, Wydawnictwo Naukowe PWN, Warszawa 2013. Przeł. M. Panafiuk, J. Pasek, A. Romaniuk.

Rodzice osób niepetnosprawnych wrócili do Sejmu. Stawiają twarde warunki, https://www. newsweek.pl/polska/spoleczenstwo/protest-rodzicow-dzieci-niepelnosprawnychw-sejmie/5rck7es (February 2019).

Szacka B., Czas przeszty, pamięć, mit, Scholar, Warszawa 2006.

Sztompka P., Socjologia. Analiza społeczeństwa, Znak, Kraków 2002. 
Tendera M., Protest jako mechanizm równoważenia nierówności społecznych, „Kultura i Społeczeństwo", 2013, no. 2, (pp. 110-132).

Trwa protest opiekunów osób niepetnosprawnych. Jak wyglada ich życie na sejmowych korytarzach? „Będziemy walczyć. Mamy mnóstwo sity”, https://polskatimes.pl/trwaprotest-opiekunow-osob-niepelnosprawnych-jak-wyglada-ich-zycie-na-sejmo wych-korytarzach-bedziemy-walczyc-mamy-mnostwo-sily/ar/13128666 (February, 2019).

Wilmont W.W., Hocker J. L., Konflikty między ludźmi, Wydawnictwo Naukowe PWN, Warszawa 2011. Transl. into Polish by M. Höffner.

"Wywalczyliśmy kolejny kamyczek". Protestujący rodzice spisali swoje postulaty https:// www.tvn24.pl/wiadomosci-z-kraju,3/sejm-protest-rodzicow-dzieci-niepelnospraw nych-spisali-postulaty,831084.html (February 2019).

Zaczyński W. P., Statystyka w pracy badawczej nauczyciela, Żak, Warszawa 1997. 